\title{
Local history and museology in Dagestan: trends and prospects of interrelated development
}

\author{
Eldar Eldarov - Murtazali Gadzhiev
}

\author{
Professor Eldar M. Eldarov, Doctor of Geographical Sciences. \\ Faculty of Management, Daghestan State University. \\ Chairman of the Daghestan branch of the Russian Geographical Society, \\ Makhachkala, Russian Federation \\ e-mail: geodag@mail.ru \\ ORCID: 0000-0002-9873-4437
}

Professor Murtazali S. Gadzhiev, Doctor of Historical Sciences.

Head of the Department of Archeology, Institute of History,

Archeology and Ethnography, Daghestan Federal Research Centre of RAS,

Makhachkala, Russian Federation

e-mail: murgadj@rambler.ru

ORCID: 0000-0002-4592-0527

Muzeológia a kultúrne dedičstvo, 2021, 9:4:99-113

DOI: $10.46284 / \mathrm{mkd} .2021 .9 .4 .7$

Local history and museology in Dagestan: trends and prospects of interrelated development

The article describes the historical periods of development two closely related fields of activity in Daghestan (Russia) - local history and museology. Within each period, the authors highlight the stages of the local history and museum initiative of the local intellectuals and educators. The spatio-temporal dynamics of the network of local history museums in the context of the republic's municipalities is analysed. The features of the evolution of local lore and museum affairs are revealed in the light of the prospects for the popularisation of the rich natural and cultural heritage of the "Country of the Mountains". The issues surrounding the formation of effective museum and tourist clusters on this territory are discussed.

Keywords: local lore studies, local history museums, cultural tourism, museum and tourist cluster, Daghestan

\section{Introduction}

Daghestan, the name of which translates as the "Land of Mountains", is located in the north-east of the Caucasus and the western coast of the Caspian Sea. The Republic of Daghestan occupies a little more than 50,000 square kilometers - an area that exceeds that of such countries as the Netherlands, Denmark, and Switzerland. The "Land of Mountains" is a tiny corner of our world, which is diverse and beautiful both in its nature and the original cultures of numerous ethnic groups living in it. Due to its geographical location between Europe and Asia, between the Caucasus Mountains and the Caspian Sea, Daghestan has had close and various ties with many peoples since ancient times, acting as a kind of "crossroads of cultures and civilizations", the bridge between two continents - Europe and Asia. ${ }^{1}$

Objects of the historical, cultural, and natural heritage of Daghestan have long been in the focus of experts in various fields - historians, geographers, ethnographers, biologists, linguists, and geologists. However, amateur study of such heritage has also long been a hobby for many

${ }^{1}$ GAMZATOV, G. (ed.). Dagestan na perekrestke kul'tur i civilizacij. Moscow: Nauka, 2011, p. 5. 
E. Eldarov - M. Gadzhiev: Local history and museology in Dagestan: trends and prospects...

people. The interest of Russian and foreign tourists in the unique monuments of nature, history, and ethnic culture of Daghestan has been growing. ${ }^{2}$ This process is greatly facilitated on the one hand by the stabilisation of the socio-political situation in the national regions of the South of Russia, and, on the other, by the noticeable increase in the flow of cultural tourists from all over the world.

In the modern age of the tourist boom, local history museums, located both in cities on the plain and in remote mountain villages of Daghestan, are of particular importance. Targeted funding from the federal and municipal budgets, which previously served as the only source of financial support to the museum institutions of the republic, is now complemented with investments made by businessmen interested in profit from the flow of tourists and leisure industry. Increased attendance of Daghestan's local history museums by both the local population and visiting tourists has been recorded.

\section{Experience and methodology}

The knowledge about the natural, ethnocultural and socio-economic environment of a particular state or its region, which has been developing over the centuries, ultimately serves, firstly, in forming school and university courses for studying the geography, history, and culture of these territories, and secondly, to justify the content of exhibitions at state, district, and local museums. ${ }^{3}$ The Russian regional knowledge aimed at improving the theory and practice of museum activities is traditionally referred to as "kraevedenie" (local lore studies), and the institution itself, being the repository of objects and information about the natural history and material and spiritual culture of the people of a particular territory - "kraevedchesky museyl?" (local lore museum). ${ }^{4}$

Due to the rapid growth of recreational travel, local history museums are becoming a real segment of the tourist market and one of the ways to achieve success in the economic development of a tourist destination. ${ }^{5}$ This trend leads to an increase in museum employees' responsibility in terms of adequately responding to recreational demand and employing appropriate strategies for the development of museology. ${ }^{6}$ Equally important is the introduction of innovations, including multimedia forms of museum exhibits, the creation of appropriate advertising products, the digitisation of rare text manuscripts, as well as the protection of historical and architectural

\footnotetext{
${ }^{2}$ AMUTINOV A.M. et al. Rynok $i$ upravlenie turizmom v regione. Makhachkala: Delovoy Mir, 2003, p. 28.

3 TILBURY, D. \& WILLIAMS, M. (eds.) Teaching and learning geography. London and New York: Routledge, 1997; HURREN, W. School Geography and Academic Geography: Spaces of Possibility for Teaching and Learning. In: SEARS, A. and WRIGHT, I. (eds.). Challenges \& Prospects in Canadian Social Studies. Vancouver: BC, Pacific Educational Press, 2004; PERERA, K. The Role of Museums in Cultural and Heritage Tourism for Sustainable Economy in Developing Countries. In: International Conference on Asian Art, Culture and Heritage. August, 2013. Accessed 20 January 2021, https://www.researchgate.net/publication/237099471

${ }^{4}$ SCHMIDT, S., ed. Kraevedenie v Rossii. Istoriya, sovremennoe sostoyanie, perspektivy razvitiya. Moscow: Moskvovedenie, 2004.

${ }^{5}$ MCLEAN, F.C. A marketing revolution in museums? In: Journal of Marketing Management, Vol. 11, No. 6, 1995; KIRSHENBLATT-GIMBLETT, B. Destination Culture: Tourism, Museums, and Heritage. Berkeley: University of California Press, 1998; MCKERCHER, B., DU CROS, H.. Cultural Tourism: The Partnership Between Tourism and Cultural Heritage Management. New York: The Haworth Hospitality Press, 2002; Getting cultural heritage to work for Europe. Report of the Horizon 2020 Expert Group on Cultural Heritage. Luxembourg: Publications Office of the European Union, 2015. ${ }^{6}$ KOTLER, N. G., KOTLER, Ph. \& KOTLER, W. I. Museum marketing and strategy: designing missions, building audiences, generating revenue and resources. 2nd ed. San Francisco: Jossey-Bass Publishers, 2008; GIRARD, L.F., NIJKAMP, P. Cultural Tourism and Sustainable Local Development. Ashgate, 2009.
} 
landscapes. ${ }^{7}$ Such smart technologies are currently being mastered by museum staff in Daghestan. ${ }^{8}$

The need of residents of highly urbanised areas for wildlife and loci of a different ethnic culture leads to the "compression" of geographical space, which is largely facilitated by modern high-speed and cheap transportation. ${ }^{9}$ A special contribution to reducing the parameters of recreational space-time relations is also made by local history museums, which satisfy tourists' interest in the history and geography of the destination with attractive mythology. ${ }^{10}$ The use of geographic models of Daghestan is especially effective in demonstrating the physicalgeographical "compression" of recreational space-time relations due to the formation of museum institutions in remote areas of the territory, as if "compressed" in the direction from East to West into three distinct altitudinal climatic stages - plane, foothills, and mountains. ${ }^{11}$

The analysis of the peculiarities of the development of the local lore and the territorial structure of the museum system of Daghestan is primarily aimed at establishing possible ways and means of economic activation of underdeveloped mountain areas through the rise of cultural tourism in them. Rural museums of local lore may well be considered promising centres of the future museum and tourist clusters on local and regional scales. The methods of logical, statistical, historiographical, and economic-geographical analysis are applied; foreign and domestic experience in studying the issues and prospects of cultural tourism as a factor of socio-economic growth of depressed agricultural territories is used.

\section{Milestones in the history of local lore and museology}

When studying the history of geographical discoveries, research, and museum activities in Daghestan, it is crucial to take into consideration not only Russian-language sources, but also earlier Arabic ones. The latter were of practical importance mainly in the pre-war (before the beginning of the Caucasian War in the nineteenth century) period and are represented by numerous informational pieces in Arabic, revealing, among other things, the historical, ethnographic and natural heritage of Daghestan. ${ }^{12}$ For example, a semblance of a local history museum of the mountain peoples of Daghestan was a historical and ethnographic gallery that functioned for decades at the central mosque of the mountain village of Gimra - the birthplace of the famous Imam Shamil. Although it ceased to exist during the Caucasian War, the memory of it is still preserved in the legends of the inhabitants of Gimra and the surrounding villages of mountainous Daghestan.

\footnotetext{
${ }^{7}$ EATH, C., VOM LEHN, D. \& OSBORNE, J. Interaction and interactives: collaboration and participation with computer-based exhibits. In: Public Understanding of Science, Vol. 14, No. 1, 2005; ROGERIO-CANDELERA, M.A. (ed.). Science, Technology and Cultural Heritage. London: CRC Press, 2014; TALAMO, M., VALENTINI, F., DIMITRI, A. \& ALLEGRINI, I. Innovative Technologies for Cultural Heritage. Tattoo Sensors and AI: The New Life of Cultural Assets. In: Sensors, Vol. 20, No. 7, 2020; GEORGOPOULOU P., KOLIOPOULOS, D. \& MEUNIER, A. The dissemination of elements of scientific knowledge in archaeological museums in Greece: socio-cultural, epistemological and communicational/educational aspects. In: Scientific culture, Vol. 7, No. 1, 2021.

${ }^{8}$ GADZHIEV, M.S., MUGADOVA, M.V. \& ELDAROV, E.M. Razvitie kraevedeniya i muzejnogo dela v Dagestane: ocherk istorii. In: Nasledie vekov, No.1, 2018.

${ }^{9}$ Getting cultural heritage to work..., p. 6.

${ }^{10}$ VEDENIN, Y.A., ELDAROV, E.M. Rol' N.S. Mironenko v gumanizacii rossijskoj rekereacionnoj geografii. Nikolaj Mironenko. Stranicy zhizni. Nauchnye idei i raboty. Pedagogicheskaya deyatel'nost'. Vospominaniya. Moscow: MSU, 2015.

${ }^{11}$ OSMANOV, A.M. Moj kraj Dagestan. Moscow: Mysl, 1979; MUDUEV, Sh.S., ELDAROV, E.M. Severnyj Kavkaz $i$ Dagestan: social'no-geograficheskie problemy gornyh regionov. Makhachkala: Dagestan Scientific Center RAS, 2002.

${ }^{12}$ SHIKHSAIDOV, A.R. Dagestan v X-XIV vv. Opyt social'no-ekonomicheskoj harakteristiki. Makhachkala: Dagknigoizdat, 1975.
} 
The pre-Soviet period of the formation of the Russian-language local history can be divided into two stages: a scientific-intelligent stage and a missionary-educational stage. The first comprehensive studies of the social and natural "fabric" of Daghestan in the Russian language are already evident in the fifteenth century, when representatives of the military, diplomatic, and commercial institutions of tsarist Russia started to collect and summarise "intelligence"

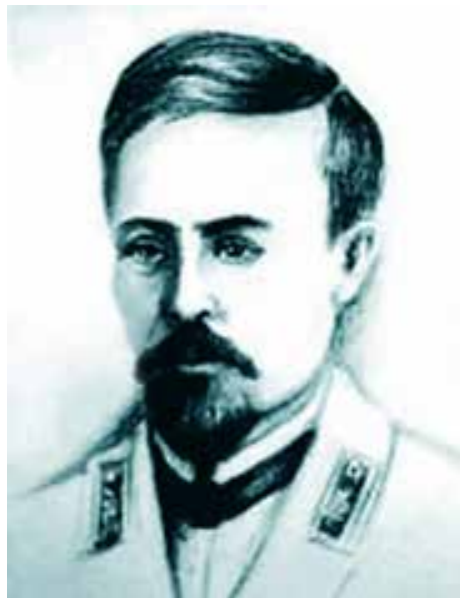

Fig. 1: Ivan Kostemerevsky (1813-1891) - the founder of the Russian-language study of local lore in Daghestan (Photo courtesy of the Central State Archive of Dagestan)

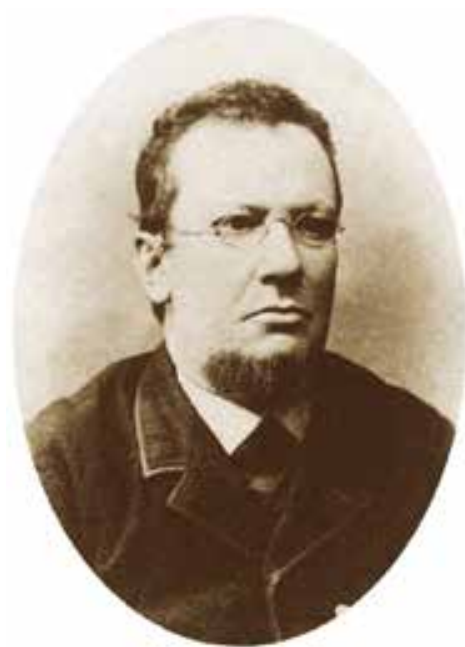

Fig. 2: Yevgeny Kozubsky (18511911) - the founder of the Russianlanguage museology of Daghestan (Photo courtesy of the Central State Archive of Dagestan) about the nature, economy, and population of the "Land of Mountains". One of the first of such "local historian-scouts" was Afanasy Nikitin, whose information about the possible ties and expansions of the Russian Empire in the South is now considered a historical monument of intelligence and analytical information. ${ }^{13}$ Fedot Kotov, Mikhail Tikhonov, Efim Myshetsky, Artemy Volynsky, Ivan Brekhov, Grigory Shakhmatov, Fedor Leontiev, Mikhail Baryatinsky, Fedor Volkonsky, Artemy Sukhanov, Boris Pazukhin, and others are among these "local historian-scouts", who made quite a definite contribution to the comprehensive geographical and historical-cultural study of Daghestan.

The missionary-educational stagein the history of Daghestan's local lore and museum studies was most clearly manifested in the work of Ivan Kostemerevsky (1813-1891) (Figure 1) and Yevgeny Kozubsky (1851-1911) (Figure 2). The former is rightfully considered the founder of the Russian-language local lore in Daghestan. Kostemerevsky expended his life savings on the education and healthcare of the highlanders. According to his will, "around 3,000 rubles were allocated to support artisanal industries in Daghestan through the formation of the museum". By 1910, the capital doubled, and the military governor of the Daghestan region personally assumed control over the execution of Kostemerevsky's will. The governor allocated additional funds and created a special committee overseeing the foundation of a local history museum. To fulfil the needs of this institution, a part of the building of the governor's house was allocated to the former capital of the region, the city of Temir-Khan-Shura (renamed to Buinaksk after the October Revolution), where the first museum of local Daghestan lore was opened in 1913. ${ }^{14}$

After the death of Kostemerevsky in 1891, the Head of the Statistical Department of the region, Yevgeny Kozubsky, picked up the conduction of active local history museum and educational activities in Daghestan. It should be noted that the leadership of the region, if necessary, widely used the intellectual potential of Kozubsky, involving him in major scientific and analytical research, particularly statistical,

\footnotetext{
${ }^{13}$ KARPENKO, A.V. Kem byl tverskoj kupec Afanasij Nikitin? In: Prose.ru 2012. Accessed 20 January 2021, https:// proza.ru/2012/10/18/1470

${ }^{14}$ ELDAROV, M.M. Otkrytyj arhiv I.S. Kostemerevskogo. Sovetsky Daghestan, No. 1, 1991.
} 
economic, and demographic studies. In 1901, he participated in the organisation of the First Caucasian Congress of Artisanal Industry workers, where he made a report on the feasibility of organising museums in the region, defined their goals, and gave a description of various types of future Daghestan museums. E. Kozubsky did not live to see the official opening - just one year later, in 1913 - of the first republican museum, named "Kostemerevsky Handicraft Museum". The museum collected photographs dedicated to the unique objects of nature and culture of the Land of Mountains, rare documents, books, traditional Daghestani weapons, clothing, and objects of decorative and applied arts and crafts. ${ }^{15}$

The Soviet period of the development of local history and museum studies in Daghestan begins with the October Revolution of 1917 and ends in the 1980s. It can be divided into three stages - formation (1920s), stagnation (1930s-1940s) and active growth (1950s-1980s).)

During the Civil War in Daghestan (1917-1920), the funds of the Kostemerevsky museum were almost completely looted. Only the items that its employees managed to hide in their homes survived. From the huge collection of more than a thousand items, less than 400 exhibits were saved. In 1920, on the decision of the Daghestan Revolutionary Committee, the "National Museum of Daghestan" was established on the basis of the existing Kostemerevsky museum. By the beginning of 1921, it a significant number of exhibits had been collected, including rare objects of decorative-applied arts and crafts of the peoples of Daghestan. Soon the museum was closed, and all its exhibits were moved to the new capital - the city of Petrovsk (renamed Makhachkala in 1921) for the formation of the republican museum. The decision to do this was taken by the first People's Commissar of Education and Justice of the Daghestan Autonomous Soviet Socialist Republic (DASSR), Alibek Takho-Godi (1892-1937).

In November 1923, A. Takho-Godi was elected Chairman of the Daghestan Museum Committee. On his initiative, the exhibits for the republican museum were selected from the State Museum Funds of Moscow and Leningrad with the help of art historians. It is thanks to the activity and enthusiasm of this revolutionary that the modern Daghestan museums now have a rich collection of Western European art from the sixteenth to nineteenth centuries and Russian art from the nineteenth to early twentieth centuries.

In 1925, the museum received the gift of a valuable collection from the Caucasian Military History Museum in Tbilisi consisting of more than 100 items, including original paintings by Francois Roubaud ("The Capture of Gunib", "The Capture of Shamil", "The Storming of the village of Gimry", "The Capture of Akhulgo", a portrait of Imam Shamil, and portraits of participants in the Caucasian War), as well as historical relics: banners of prominent figures of the Caucasian war imams Gazi-Muhammad, Shamil, naib Hadzhi Murad, and others. In 1926, the Daghestan Museum received 182 paintings from the Museum Fund of Moscow and the Leningrad Museums, including those of such prominent painters as I. Levitan, V. Serov, I. Shishkin, V. Perov, S. Svyatoslavsky, F. Bronnikov, S. Vinogradov, and others. ${ }^{16}$

In addition to the work on the identification and return of Daghestan exhibits stored outside the republic, the museum committee of the DASSR carried out the collection of items in Daghestan itself. Expedition work, individual searches, and purchases were actively conducted. Alibek Takho-Godi's huge contribution to the formation of Soviet culture in the DASSR did not save him from political repression. In 1937, he was arrested and the Military Board of the

\footnotetext{
${ }^{15}$ MANYSHEV, S.B. S chuvstvom glubokogo pochteniya k pamyati shtab-lekarya I.S. Kostemerevskogo. (Iz istorii sozdaniya muzeya v Dagestane v nachale XX v.) In: KLYCHNIKOV, Yu. (eds.). Russian statehood in the fate of the peoples of the Caucasus [Rossiyskaya gosudarstvennost'v sud'bakh narodov Kavkaza]. Pyatigorsk, 2016.

${ }^{16}$ KAIMARAZOV, G.Sh. Obrazovanie i nauka v Dagestane v XX veke. Makhachkala: Dagknigoizdat, 2007.
} 
Supreme Court of the USSR sentenced him to death.

An equally sad fate befell the main associate of Takho-Godi - the first head of the Daghestan Museum of Local Lore Dmitry Pavlov (1884-1931), on whose initiative the Association of North Caucasian Mountain Local Lore Organisations was established in Makhachkala. D. Pavlov was arrested and died in the NKVD's prison in April 1931. ${ }^{17}$ Dmitry Pavlov lived only 47 years, but managed to contribute significantly to the development of museology and local history in Daghestan (Figure 3).

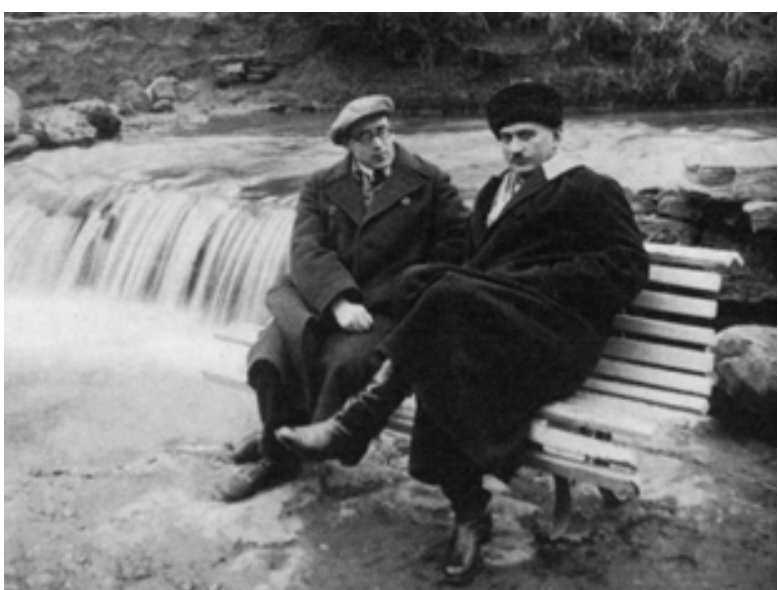

Fig. 3: Dmitry Pavlov and Alibek Takho-Godi (on the right) on vacation in the main recreational area of the North Caucasus, Kislovodsk, late 1920s. (Photo courtesy of the Central State Archive of Dagestan)

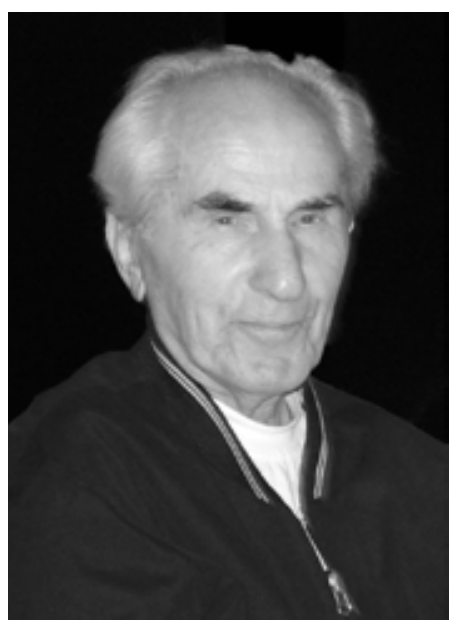

Fig. 4: Bulach Gadzhiev (19192007) - founder of the mass local lore movement in Daghestan (Photo from the family archive of Murtazali Serazhutdinovich Gadz̧biev)
By the decree of the Council of People's Commissars of the Republic of Daghestan, the Museum was reorganised into the Central Museum of the DASSR in 1940. The staff of the museum numbered 25 people. The structure of the museum included the Republican Museum of Local Lore in Makhachkala, the Stalin Historical and Revolutionary $\mathrm{Mu}-$ seum in Buinaksk, the Local History Museum in Derbent, the Suleiman Stalsky Literary Museum in the village of Ashaga-Stal, as well as the local history museum in the village of Akhty. By that time, more than 27,000 exhibits were stored in the Central Republican Museum.

In 1942, due to the danger of a breakthrough of the fascist forces to Makhachkala, all the exhibits of the Central Museum were evacuated to the southernmost city of Daghestan, Derbent, and the museum's premises were allocated to accommodate the military. It was reopened in May 1943 in Makhachkala, when the defense of the Caucasus ended in victory. Unfortunately, a number of exhibits were lost or damaged during the move; the museum's research activities were suspended, and its staff numbers were significantly reduced. ${ }^{18}$

It should be noted that in the 1930s and 1940s, representatives of the Daghestani intelligentsia felt a real threat of being dishonored by the state's ideological and punitive services, of being branded "bourgeois nationalists" and, moreover, "the agents of foreign intelligence". This factor limited their creative initiatives in terms of the deployment of local lore, museum, and general cultural and educational activities on the territory of the Daghestan ASSR.

The self-devotion of the Daghestani intelligentsia in the field of local history and museology became widespread in the

\footnotetext{
${ }^{17}$ LYSENKO, Y.M. Dmitrij Mihajlovich Pavlov-pervyj direktor Dagestanskogo nauchno-issledovatel'skogo instituta: shtrihi k portretu. In: Bulletin of the Daghestan Scientific Center. No. 44, 2012.

${ }^{18}$ NAGIEVA, M.K. K voprosu o vozniknovenii i razvitii muzejnogo dela v Dagestane v konce XIX-pervoj polovine XX v. In: Questions of museology, No. 2, 2010.
} 
1950s. Since that time, a mass local history movement was born in the schools of the republic. Thus, in 1952, in one of the schools of Buinaksk, on the initiative of the history teacher Bulach Gadzhiev (1919-2007), the first school local history club was created (Figure 4). The members of the circle made numerous trips to various corners of Daghestan noted for their history and natural environment. B. Gadzhiev is the author of perhaps the most popular local history books in the republic, dedicated to the history and culture of the peoples of Daghestan. During his devoted activity in the field of local historical lore, he published more than 30 books. ${ }^{19}$ The brilliant local history innovations of Bulach Gadzhiev were picked up by other teachers of the republic, especially in rural areas. For many reasons, Daghestan now has a relatively large number of school museums, on the basis of which several branches of the National Museum of the Republic were later formed.

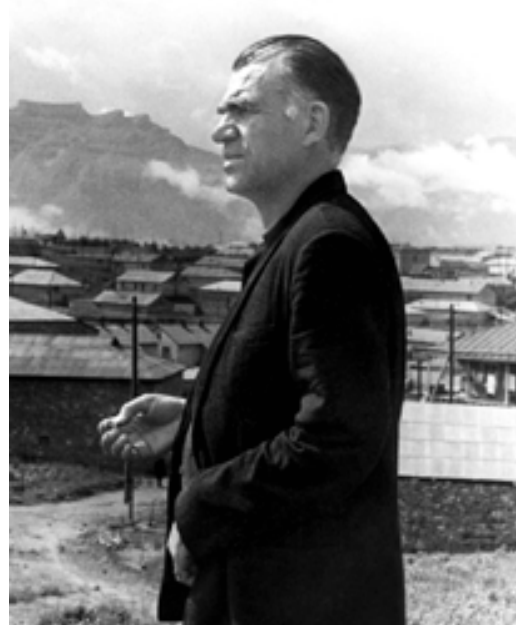

Fig. 5: Magomed Eldarov (1921-1992) - founder of the geographical direction of Daghestan local lore (Photo from the family archive of Eldar Magomedovich Eldarov)

In the 1950s, Magomed Eldarov discovered his pedagogical talent [Figure 5]. Being one of the most famous geographers-educators, he was the first to apply scientific evidence and methods to the practices of geographical and patriotic education of schoolchildren, based on local material. The consecutive implementation of M. Eldarov's ideas in the pedagogical process started immediately after his time at the post-graduate Institute of pedagogic methods of the Academy of Pedagogical Sciences of the RSFSR, wherein 1952 he upheld his candidate thesis on the subject of "Regional principle of the geography of the USSR in Daghestan schools". ${ }^{20}$ As the staff of the Institute noted in their review article, the work of M. M. Eldarov "has quite a significant value". ${ }^{21}$

In the mid-1950s, on the initiative of Vadim Himmelreich, head of the Local History Department of the Central Republican Library (Makhachkala), a library circle of local historians and geographers was created. In 1959 in the Ministry of Public Education of the DASSR, as well as in the Institute for Advanced Training of Teachers and the Pedagogical Institute, a decision was made to establish the Daghestan branch of the All-Union Geographical Society. V. Himmelreich was appointed as the society's head. ${ }^{22}$

A collective monograph published in 1956 under the editorship of the famous writer Dmitry Trunov (1913-1973), devoted to the results of the work of the Daghestan Museum of Local Lore for 30 years of its existence, can be considered a major milestone in the historiography of Daghestan's museology. The book reflects various types of work on the identification, collection, and preservation of important materials of the historical, cultural, and natural

\footnotetext{
${ }^{19}$ DAVYDOV, A.N. Uchitel'. Makhachkala: Epokha Publishing House, 2014.

${ }^{20}$ ELDAROV, M.M. Kraevedcheskij princip prepodavaniya geografii SSSR v sed'myh klassah dagestanskih shkol. Abstract of the dissertation thesis of the candidate of pedagogical sciences. Moscow: Institute for Teaching Methods of the Academy of Pedagogical Sciences of the RSFSR, 1951.

${ }^{21}$ GERASIMOVA, T.P., KORINSKAYA, V.A. Iz opyta kraevedcheskoj raboty. In: MATRUSOV, I. (ed.). Kraevedenie $i$ kraevedcheskij podhod v prepodavanii geografi: Sbornik statej. Moscow: APN RSFSR, 1963.

${ }^{22}$ ELDAROV, E.M. Osobennosti formirovaniya Dagestanskogo otdeleniya Russkogo geograficheskogo obshchestva. Voprosy geographii, No. 151, 2020.
} 
E. Eldarov - M. Gadzhiev: Local history and museology in Dagestan: trends and prospects...

heritage of the republic. ${ }^{23}$

In 1968 the Daghestan Museum of Local Lore was relocated to a new building on the central square of Makhachkala. The staff of the museum, under the direction of Davud Kazhlaev (1913-1999), launched new expositions dedicated to the nature, history, and culture of Daghestan in the pre-Soviet and Soviet periods. It should be highlighted that D. Kazhlaev belongs to the cohort of those outstanding Daghestani museum and local historians whose brilliant research and writing talent enriched the 1960s and 70s. He is the author of the famous book, "Monuments of History and Culture of Daghestan". ${ }^{24}$

In 1977, by the resolution of the Council of Ministers of the DASSR, in order to further improve the scientific and methodological management of museum work, and improve the leisure services for tourists and the local population, the Republican Museum of Local Lore was turned into a United Historical and Architectural Museum. The museum administered the following branches: Buynakskiy Historical-Revolutionary Museum, the Derbent and Akhtynsky Local History Museums, the Memorial Museum of Suleyman Stalsky in the village of AshagiStal, the State Literary-Memorial Museum of Gamzat Tsadasa in the village of Khunzakh, and the Pyotr Bagration Local Lore Museum in the city of Kizlyar. By 1990, the network of branches expanded to include the Museum of Military Glory and the Theatre Museum in Makhachkala, and the Museum of Military Glory in Buinaksk; the Derbent Museum was converted into the State Derbent Museum-reserve.

The 1970s and 1980s were the period of formation for small museum expositions of local lore (zoological, geological, historical, archaeological, etc.) at the largest faculties of Daghestan's universities and research institutes of the Daghestan branch of the USSR Academy of Sciences. In the mid-1970s, a mini-museum of local lore was founded at the Faculty of Natural Geography of the Daghestan Pedagogical Institute, the fund of which would expand mainly due to regular expeditions by students and teachers of the faculty to remote areas of the republic. ${ }^{25}$

Post-Soviet period. Oddly enough, it was in the 1990s that, despite the serious difficulties that arose in the activities of almost all institutions of social and cultural profile in the region, scientific, local history, and museum studies nevertheless broke new ground. To a great

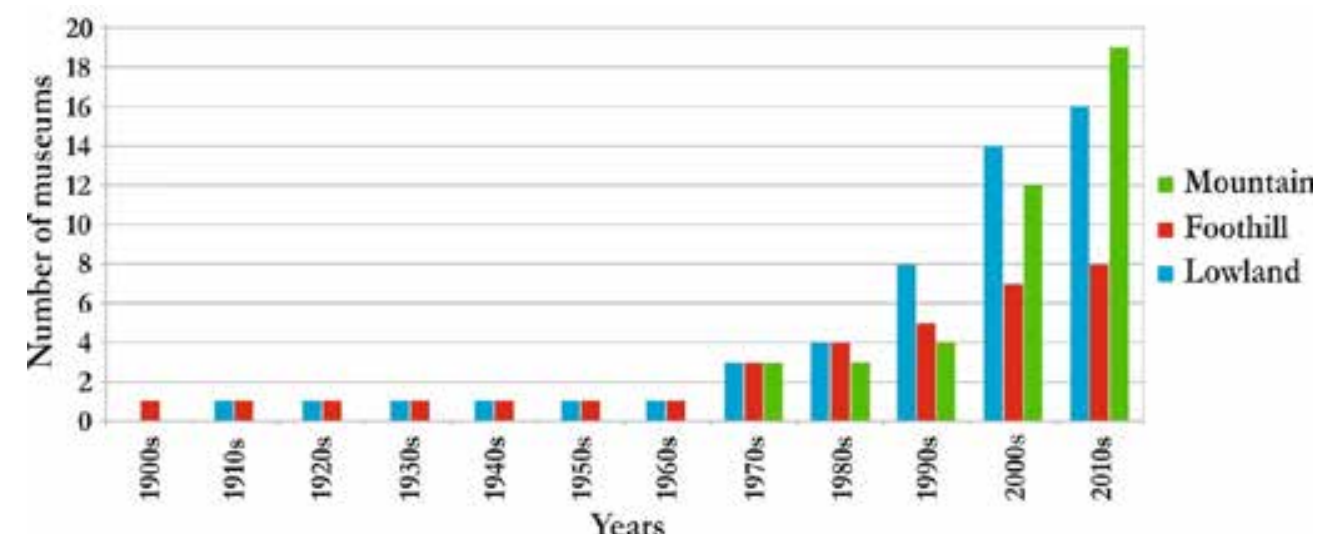

Fig. 6: Changes in the number of museums in highland areas of Daghestan over the last century (Compiled by the authors)

\footnotetext{
${ }^{23}$ TRUNOV, D., ed., Dagestanskij respublikanskij kraevedcheskij murej. Makhachkala, Dagknigoizdat, 1956.

${ }^{24}$ KAZHLAEV, D.G. Pamyatniki istorii $i$ kul'tury Dagestana. Makhachkala: Dagknigoizdat, 1967.

${ }^{25}$ MAGOMEDOV, I.M. Dobryj sled na rodnoj Zemle. Makhachkala: DGPU, 1997.
} 
extent, this was the result of a significant increase in national consciousness and people's interest in their own history and culture. It is worth noting that three-quarters of all modern museums in Daghestan were established in the period starting from 1990. However, the most encouraging thing about this trend is that half of all the museums formed at this time became the property of numerous rural areas of Mountainous Daghestan (Figure 6).

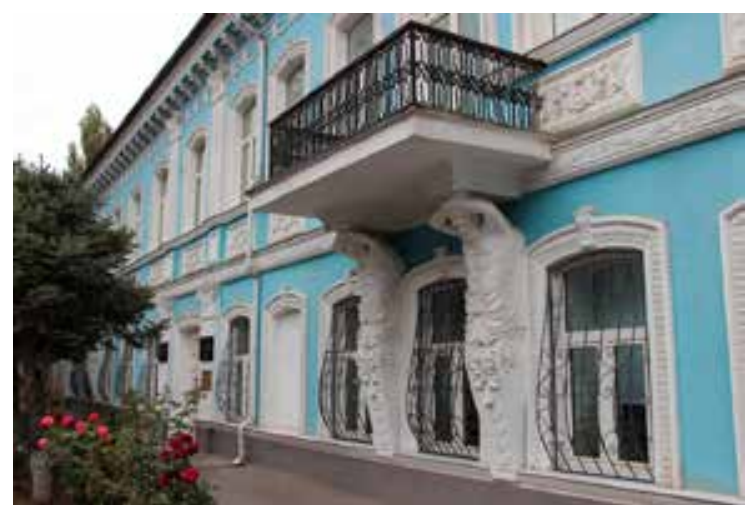

Fig. 7: Takbo-Godi National Museum of the Republic of Daghestan, Makhachkala (Photo courtesy of the Takho-Godi National Museum of Daghestan)

The market economy has made significant adjustments to the work of local history structures in Daghestan. Being real estate objects, many cultural, historical, archaeological, and architectural monuments that had not yet undergone the necessary institutionalisation were privatised by entrepreneurs. By this, we mean by people who often have nothing to do with either the sphere of culture or local history. At the same time, there have also been major positive changes in the development of museum studies. Thus, for instance, the Daghestan State United Historical and Architectural Museum, which was named after Alibek Takho-Godi in 2006, was planned to be relocated to a new, more spacious and historically significant building by 2017 - the pre-revolutionary merchant house-palace, located in perhaps the most comfortable area of the Daghestan capital (Figure 7). On the decision of the Head of the Republic, Ramazan Abdulatipov, the Daghestan State United Historical and Architectural Museum was renamed the Takho-Godi National Museum of the Republic of Daghestan.

Currently, there are 42 museums in the republic, 41 of which are branches of the National Museum of the Republic of Daghestan. Of these, 28 museums, or 65\%, have a historical and local history profile, and 7 museums are memorial house-museums. There are also two museums of Military Glory (in Makhachkala and Buinaksk), a historical-life museum in the

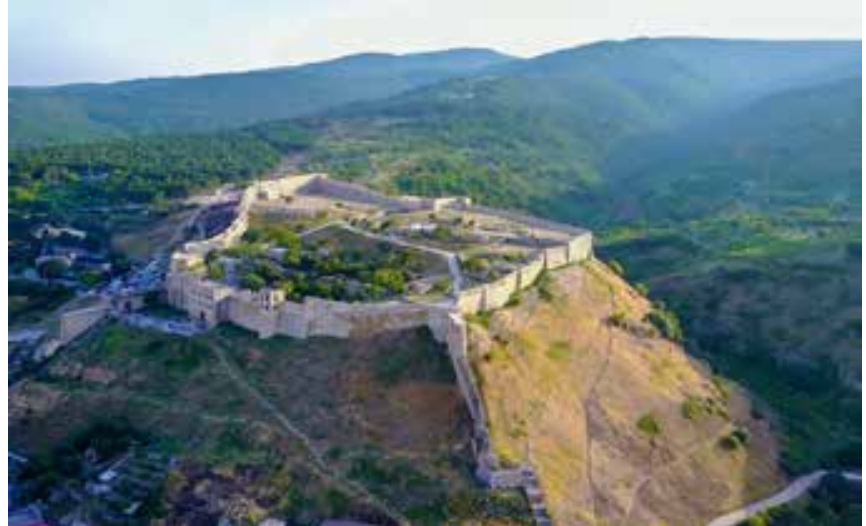

Fig. 8: Derbent citadel Naryn-Kala (Photo from source: https:/ / livingheritage.ru/brand/respublika-dagestan/krepost-naryn-kala) village of Sulevkent, and industrial and theatrical museums (both in Makhachkala). An important event took place in 2003, when the monuments of Derbent - the Naryn-kala citadel (Figure 8), and the Ancient City and Fortress Buildings - were added to the UNESCO World Heritage List (criteria: III, IV). ${ }^{26}$ Another joyful event in the cultural life of the republic and the whole country was the celebration of the 2000th anniversary of Derbent in 2015.

\footnotetext{
${ }^{26}$ Citadel, Ancient City and Fortress Buildings of Derbent. Accessed 20 January 2021, https://whc.unesco.org/en/ list/1070/
} 


\section{Innovations in museology}

One of the most essential directions in museum work is the popularisation of the important monuments of nature, history, and culture with the help of art projects. These include thematic exhibitions of printed publications, photographs, artifacts, and relics, displayed in museums and libraries, which reveal significant moments in the history of Daghestan, and the fate and exploits of its notable representatives. Thus, in November 2016, the Museum of the History of the city of Makhachkala organized the exhibition "Evgeniy Gvozdev: The Solo Mariner" dedicat-

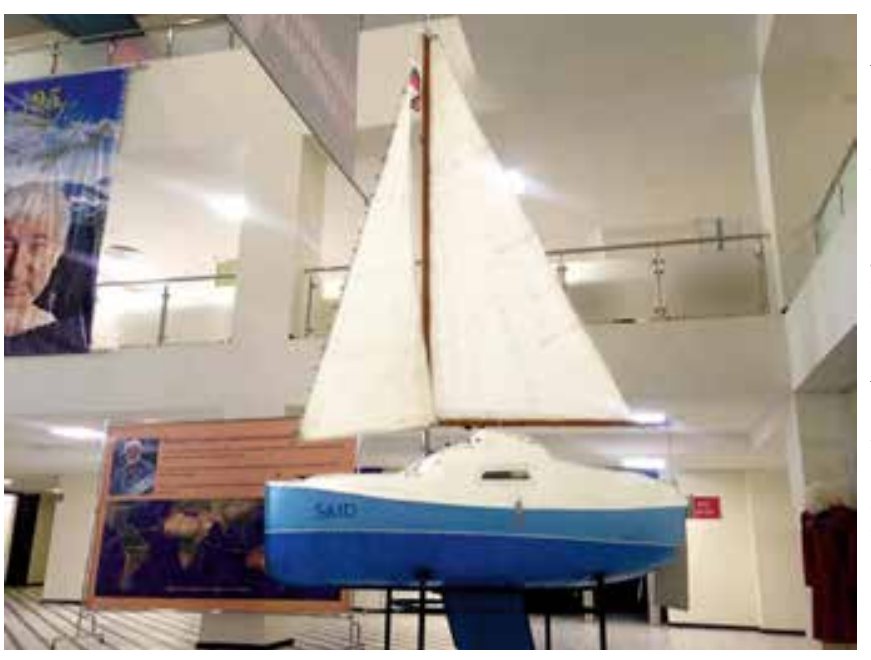

Fig. 9: Yevgeny Gvozdev's mini-yacht in the museum park, "Russia is my history", Makhachkala (Photo courtesy of the Dagestan Branch of the Russian Geographical Society)

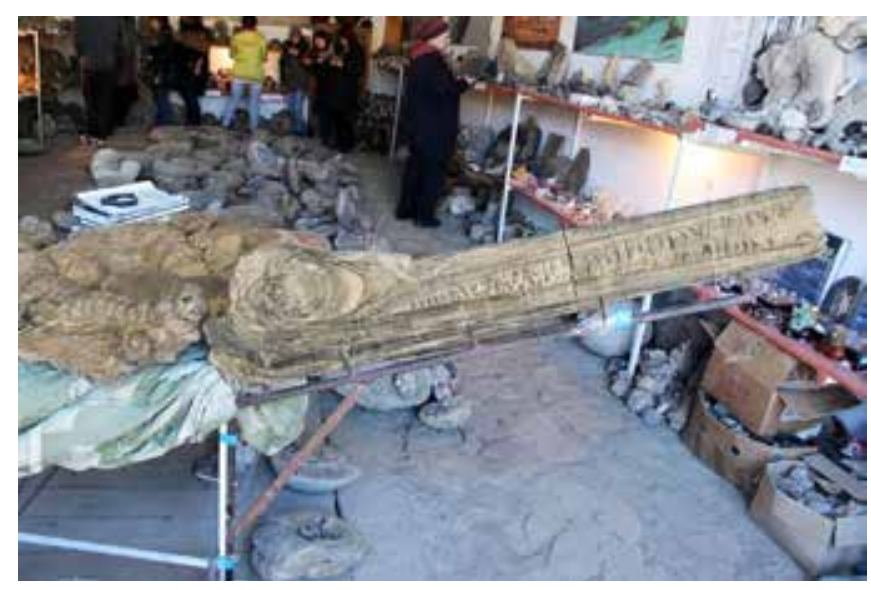

Fig. 10: Private museum of paleontology owned by Omar Khapisov, Lower Chugli (Photo courtesy of the Takho-Godi National Museum of Daghestan)

- a reptile that lived in the waters of the Tethys Ocean more than a hundred million years ago (Figure 10). ed to the Daghestani solo mariner who completed two circumnavigations of the globe on mini-yachts. ${ }^{27}$ Moreover, two years later, with the assistance of the Daghestan Geographical Society, a permanent exhibition dedicated to E. Gvozdev (1934-2008), "Russia is my history", was created in the new Makhachkala Museum Park (Figure 9).

Immersion in national traditions has become a common method of attracting visitors to Daghestan's restaurants. Among these, the restaurant-museum "On Lermontov street" in Makhachkala stands out the most. The restaurant brings a rich ethnic flavor to both the food and the staff's clothing, which is combined with a wide collection of museum and ethnographic exhibits that make up the interior of this gastronomic place.

Thanks to the Internet, many professional paleontologists have learned about the domestic museum of fossilised remains of pre-historic animals, founded in the mountainous Daghestan village of Nizhny Chugli by a local beekeeper and passionate amateur paleontologist, Omar Khapisov. The museum's main exhibit is the well-preserved remains of an ichthyosaur

${ }^{27}$ ELDAROV, E.M., SHMERLING, G.V. Krugosvetnye plavaniya Evgeniya Gvozdyova. Beau Bassin, Mauritius: LAMBERT Academic Publishing, 2018. 
The exchange of information via the global network has become a new norm for professional museologists and amateur local lore historians. While amateur local lore historians limit their research to regional scales, the professionals usually aim at a more extensive and multifaceted Internet environment. At the same time, as experts rightly note, not only local history and museum studies are enriched by the latest scientific achievements in the fields of geography, history, and cultural studies; there is also a general "spatial turn" in museology. ${ }^{28}$

Currently, the number of republican, district and village websites, as well as personal accounts on global social platforms such as Facebook, VKontakte, Twitter, etc., full of information about the monuments of nature, history, and culture in Daghestan, is noticeably increasing. This trend reflects people's growing interest in local history, which is mainly implemented spontaneously and, unfortunately, not always in a scientifically based way. Sadly, a large amount of local history and museum work is still carried out with a limited understanding of what belongs to the sphere of proper professional scientific knowledge. ${ }^{29}$

The current surge in the museum and local history activity of the population reflects the general trend of the revival of Daghestan's national culture and national identity. However, this process is mostly chaotic and disorganised, and has significant flaws in its scientific and methodological plan. Therefore, it seems appropriate to combine the efforts of disparate enthusiasts and scientists for better scientific and methodological support of museums, and to turn the local history movement in a constructive direction towards protecting and popularising the monuments of natural and cultural-historical heritage of Daghestan.

\section{Conclusion}

The wide network of museums that exists in Daghestan is in urgent need of modernisation and professional scientific provision. Museums need to be provided with modern equipment, and innovative technologies for lighting stands and exhibits. The task of creating special repositories for numerous archaeological materials, most of which are not represented in the expositions, is important. At the same time, there is an acute shortage of professional museum workers and specialist curators, tour guides, museologists, museum managers, designers, etc.

Modern technologies provide opportunities for museums to move forward, making unique artifacts - or copies of them - available far beyond the museum halls and pavilions. On the one hand, travelling exhibitions from the capital's museums, and on the other, rural fairs and ethnocultural maydans in the cities of the republic, are invariably accompanied by the active participation of local residents. This contributes to the familiarisation of the urban youth with national traditions and relics, and the inhabitants of villages with the achievements of urban culture.

On today's agenda, one of the major tasks is to increase the level of museum work that meets the modern tourist's needs. Solving these problems will allow the creation of an attractive museum environment for cultural tourists. In this aspect, it is necessary to make greater use of the experience of leading museum experts from both Russia and abroad.

As foreign experience has shown, cultural tourism is gradually turning museums into the main centres of information support for the leisure industry. In turn, museum employees face the specific tasks of determining their institution's cultural and tourist specialisation, forming a

\footnotetext{
${ }^{28}$ GEOGHEGAN, H. Museum Geography: Exploring Museums, Collections and Museum Practice in the UK. In: Geography Compass, Vol. 4, No. 10, 2010.

${ }^{29}$ GADZHIEV, M.S., KUZNETSOV, V.A. \& CHECHENOV, I.M. Istoriya v zerkeale paranauki: Kritika sovremennoj etnocentricheskoj istoriografii Severnogo Kavkaza. Moscow: IEA RAS, 2006.
} 
E. Eldarov - M. Gadzhiev: Local history and museology in Dagestan: trends and prospects...

constant flow of tourists to museums, drawing up appropriate programs and routes, developing a package of advertising products, etc. This applies not only to complex local history museums, but also to specialised museums that reflect certain types of material and intangible heritage of the peoples of the "Land of Mountains".

Local museums act as the main accumulators of all significant cultural, historical, and natural heritage within rural tourist destinations. That's why the cooperation of tourism and museum institutions can be considered one of the real mechanisms for the socio-economic recovery of the backward territories of mountainous Daghestan, contributing to the formation of a relatively comfortable social and industrial infrastructure in rural areas, improving the well-being and cultural level of the villagers.

It is quite obvious that the strengthening of cooperation between the museum sector and tourism, and the formation on this basis of the museum-tourist clusters, will contribute to the protection and promotion of the natural and cultural heritage, and improve the image and overall socio-economic growth of the "Land of Mountains".

\section{Acknowledgment}

The authors express their deep gratitude to the chief curator of the funds of the TakhoGodi National Museum of Daghestan, Zaira Kildeeva, for providing statistics on the latest stages of the development of museology in the republic and director of the Central State Archives of Dagestan, Olga Bekaeva, for biographical information about the founders of Dagestan local history.

\section{References}

AMUTINOV A.M., ALIEV Sh.M., CHERGIZBIEV M.I., ELDAROV E.M. (2003). Rynok $i$ upravlenie turizmom $v$ regione [Market and tourism management in the region]. Makhachkala: Delovoy Mir. [n Russian] ISBN 5-7310-1271-8

Citadel, Ancient City and Fortress Buildings of Derbent. Accessed 20 January 2021, https://whc. unesco.org/en/list/1070/

DAVYDOV, A.N. (2014). Uchitel' [A Teacher]. Makhachkala: Epokha Publishing House, p. 270. [In Russian]

EATH, C., VOM LEHN, D. \& OSBORNE, J. (2005). Interaction and interactives: collaboration and participation with computer-based exhibits. In: Public Understanding of Science, No. 14, pp. 91-101. ISSN 0963-6625

ELDAROV, E.M. (2020). Osobennosti formirovaniya Dagestanskogo otdeleniya Russkogo geograficheskogo obshchestva [Features of the formation of the Daghestan branch of the Russian Geographical Society]. In: Voprosy geographii, No. 151, pp. 491-512. [In Russian] ISSN 0372-5758

ELDAROV, E.M., SHMERLING, G.V. (2018). Krugosvetnye plavaniya Evgeniya Gvozdyova [Evgeny Gvozdev's circumnavigation of the world]. Beau Bassin, Mauritius: LAMBERT Academic Publishing. [In Russian] ISBN 978-613-9-58037-8

ELDAROV, M.M. (1991). Otkrytyj arhiv I.S. Kostemerevskogo [Public archive of I.S. Kostemerevsky]. In: Sovetsky Daghestan, No. 1, pp. 11-12. [In Russian] 
ELDAROV, M.M. (1951). Kraevedcheskij princip prepodavaniya geografii SSSR v sed'myh klassah dagestanskih shkol [The principle of local lore teaching of geography of the USSR in the seventh grades of Daghestan schools]. Abstract of the dissertation thesis of the candidate of pedagogical sciences. Moscow: Institute for Teaching Methods of the Academy of Pedagogical Sciences of the RSFSR. [In Russian]

GADZHIEV, M.S., KUZNETSOV, V.A. \& CHECHENOV, I.M. (2006). Istoriya v zerkale paranauki: Kritika sovremennoj etnocentricheskoj istoriografii Severnogo Kavkaza [History in the mirror of parascience: a critique of contemporary ethnocentric historiography of the North Caucasus]. Moscow: IEA RAS. [In Russian] ISBN 5-201-00837-2

GADZHIEV, M.S., MUGADOVA, M.V. \& ELDAROV, E.M. (2018). Razvitie kraevedeniya i muzejnogo dela v Dagestane: ocherk istorii [Development of local history and museology in Daghestan: a historical study]. In: Nasledie vekov, No. 1, pp. 13-29. [In Russian] ISSN 2412-9798

GAMZATOV, G., ed. (2011). Dagestan na perekrestke kul'turi civilizacij [Daghestan at the crossroads of cultures and civilizations]. Moscow: Nauka. [In Russian] ISBN 978-5-02-037403-4

GEOGHEGAN, H. (2010). Museum Geography: Exploring Museums, Collections and Museum Practice in the UK. In: Geography Compass, Vol. 4, No. 10, pp. 1462-1476. ISSN 1749-8198

GEORGOPOULOU P., KOLIOPOULOS D. \& MEUNIER A. (2021). The dissemination of elements of scientific knowledge in archaeological museums in Greece: socio-cultural, epistemological and communicational/educational aspects. In: Scientific culture, Vol. 7, No. 1, pp. 31-44. ISSN 2407-9529

GERASIMOVA, T.P., KORINSKAYA, V.A. (1963) Iz opyta kraevedcheskoj raboty. In: MATRUSOV, I. (ed.). Kraevedenie $i$ kraevedcheskij podhod v prepodavanii geografii: Sbornik statej [From the experience of local history work. In: Local history and local history approach in teaching geography: Collection of articles]. Moscow: Academy of Pedagogical Sciences RSFSR, pp. 133-148. [In Russian]

Getting cultural heritage to work for Europe. Report of the Horizon 2020 Expert Group on Cultural Heritage (2015). Luxembourg: Publications Office of the European Union. ISBN 978-9279-46046-3

GIRARD, L.F., NIJKAMP, P. (2009). Cultural Tourism and Sustainable Local Development. Ashgate. ISBN 9781315258720

HURREN, W. (2004). School Geography and Academic Geography: Spaces of Possibility for Teaching and Learning. In: SEARS, A. and WRIGHT, I. (eds.). Challenges \& Prospects in Canadian Social Studies. Vancouver: BC, Pacific Educational Press, pp. 118-125. ISBN 1895766729

KAIMARAZOV, G.Sh. (2007). Obrazovanie i nauka v Dagestane v XX veke [Education and Science in Daghestan in the XX century]. Makhachkala: Dagknigoizdat. [In Russian] ISBN 978-5297-01010-0

KARPENKO, A.V. (2012). Kem byl tverskoj kupec Afanasij Nikitin? [Who was the Tver merchant Afanasy Nikitin?] In: Prose.ru. Accessed 20 January 2021, https://proza. $\mathrm{ru} / 2012 / 10 / 18 / 1470$ [In Russian]

KAZHLAEV, D.G. (1967). Pamyatniki istorii $i$ kul'tury Dagestana [Monuments of history and culture of Daghestan]. Makhachkala: Dagknigoizdat. [In Russian] 
E. Eldarov - M. Gadzhiev: Local history and museology in Dagestan: trends and prospects...

KIRSHENBLAT'T-GIMBLETT, B. (1998). Destination Culture: Tourism, Museums, and Heritage. Berkeley: University of California Press. ISBN 0-520-20467-0

KOTLER, N. G., KOTLER, Ph. \& KOTLER, W. I. (2008). Museum marketing and strategy: designing missions, building audiences, generating. Revenue and resources. 2nd ed. San Francisco: Jossey-Bass Publishers. ISBN 978-0-7879-9691-8

LYSENKO, Y.M. (2012). Dmitrij Mihajlovich Pavlov - pervyj direktor Dagestanskogo nauchnoissledovatel'skogo instituta: shtrihi k portretu [Dmitry Mikhailovich Pavlov - the first head of the Daghestan Research Institute: details of the portrait]. Bulletin of the Daghestan Scientific Center. No. 44, pp. 115-118. [In Russian] ISSN 1684-792X

MAGOMEDOV, I.M. (1997). Dobryj sled na rodnoj Zemle [A good trace on the native land]. Makhachkala: DGPU. [In Russian]

MANYSHEV, S.B. (2016). "S chuvstvom glubokogo pochteniya k pamyati shtab-lekarya I.S. Kostemerevskogo...". (Iz istorii sozdaniya muzeya v Dagestane v nachale XX v.) ["With a sense of deep respect, in the memory of the head physician I.S. Kostemerevsky ...". (From the history of the creation of a museum in Daghestan at the beginning of the 20th century)]. In: KLYCHNIKOV, Yu., ed., Russian statehood in the fate of the peoples of the Caucasus [Rossiyskaya gosudarstvennost'v sud'bakh narodov Kavkara]. Pyatigorsk, pp. 128-137. [In Russian] ISBN 978-5-4220-1030-1

MCKERCHER, B., DU CROS, H. (2002). Cultural Tourism: The Partnership Between Tourism and Cultural Heritage Management. New York: The Haworth Hospitality Press. ISBN 0-7890-11069

MCLEAN, F.C. (1995). A marketing revolution in museums? In: Journal of Marketing Management, Vol. 11, No. 6, pp. 601-616. ISSN 2333-6080

MIRONENKO, N.S., ELDAROV, E.M. (2016). Development tendencies and future prospects of recreation geography in Russia. In: Geography and Natural Resources, Vol. 37, No. 2, pp. 100-105. [In Russian] ISSN 1875-3728

MUDUEV, Sh.S., ELDAROV, E.M. (2002). Severnyj Kavkaz i Dagestan: social'no-geograficheskie problemy gornyh regionov [North Caucasus and Daghestan: Socio-geographical problems of mountainous regions]. Makhachkala: Daghestan Scientific Center RAS. [In Russian]

NAGIEVA, M.K. (2010). K voprosu o vozniknovenii i razvitii muzejnogo dela v Dagestane v konce XIX - pervoj polovine XX v. [On the question of the emergence and development of museum work in Daghestan at the end of the XIX to the first half of the XX century]. In: Questions of museology, No. 2, pp. 41-45. [In Russian] ISSN 2219-6269

OSMANOV, A.M. (1979). Moj kraj Dagestan [My region is Daghestan]. Moscow: Mysl. [In Russian]

PERERA, K. (2013). The Role of Museums in Cultural and Heritage Tourism for Sustainable Economy in Developing Countries. In: International Conference on Asian Art, Culture and Heritage (August, 2013). Accessed 20 January 2021, https://www.researchgate.net/ publication/237099471

ROGERIO-CANDELERA, M.A. (ed.). (2014). Science, Technology and Cultural Heritage. London: CRC Press. ISBN 9780429226540

SHIKHSAIDOV, A.R. (1975). Dagestan v X-XIV vv. Opyt social'no-ekonomicheskoj harakteristiki [Daghestan in the X-XIV centuries. Experience of socio-economic characteristics]. Makhachkala: Dagknigoizdat. [In Russian] 
SCHMIDT, S. (ed.). (2004) Kraevedenie v Rossii. Istoriya, sovremennoe sostoyanie, perspektivy razvitiya [Local lore in Russia. History, current state, development prospects]. Moscow: Moskvovedenie. [In Russian] ISBN 5-7853-0406-6

TALAMO, M., VALENTINI, F., DIMITRI, A. \& ALLEGRINI, I. (2020). Innovative Technologies for Cultural Heritage. Tattoo Sensors and AI: The New Life of Cultural Assets. In: Sensors, Vol. 20, No. 7. ISSN 1424-8220

TILBURY, D., WILLIAMS, M., eds. (1997). Teaching and learning geography. London and New York: Routledge. ISBN 10-041514244X

TRUNOV, D., ed. (1956). Dagestanskij respublikanskij kraevedcheskij murej [Daghestan Republican Museum of Local Lore] Makhachkala: Dagknigoizdat. [In Russian]

VEDENIN, Y.A., ELDAROV, E.M. (2015). Rol' N.S. Mironenko v gumanizacii rossijskoj rekreacionnoj geografii. [Role of N.S. Mironenko in the humanisation of Russian recreational geography]. In: KOLOSOV, V., MILANOVA, E., eds., Nikolaj Mironenko. Stranicy z̧hizni. Nauchnye idei i raboty. Pedagogicheskaya deyatel'nost'. Vospominaniya [Nikolay Mironenko. Pages of life. Scientific ideas and works. Pedagogical activity. Memories]. Moscow: Moscow State University, pp. 101-111. [In Russian] ISBN 978-5-19-011089-0 